Reprod. Nutr. Dévelop., 1983, 23 (2 B), 357-366.

\title{
The structure of the insulin receptor: studies using external and internal labeling techniques
}

\author{
E. VAN OBBERGHEN $\left({ }^{1}\right), \operatorname{M} . \operatorname{KASUGA}\left({ }^{*}\right)$, J. A. HEDO $\left({ }^{*}\right)$ \\ (1) Laboratoire de Médecine expérimentale, INSERM U. 145, \\ Faculté de Médecine, Chemin de Vallombrose, 06034 Nice Cedex, France. \\ (*) Diabetes Branch, National Institutes of Health, Bethesda, U.S.A.
}

\begin{abstract}
Summary. Using both biosynthetic and external labeling techniques, we have demonstrated that the insulin receptor consists of two major subunits with a molecular weight of approximately 135,000 and 95,000 , respectively. These two major subunits are glycoproteins. Our data and observations from other laboratories have led to the suggestion that the insulin receptor is a heterodimer of the 134,000 and 95,000 subunits and, in fact, has an immunoglobulin-like structure with heavy and light chains held together by disulfide bonds. Biosynthetic studies showing the incorporation of all four labeled monosaccharides (fucose, mannose, galactose and glucosamine) into the two major subunits of the insulin receptor suggested that both subunits were likely to contain carbohydrate chains of the complex, N-linked type. External labeling techniques demonstated that a portion of the protein and carbohydrate moiety of both subunits was exposed at the external cell surface. Further, labeling of the external oriented carbohydrates revealed remarkable differences in the nonreducing termini of the carbohydrate chains of both major subunits. Indeed, in the Mr 134,000 subunit, there appeared to be more exposed galactosyl or $\mathrm{N}$-acetylgalactosaminyl (or both) residues, whereas the $\mathrm{Mr}$ 95,000 subunit seemed to have a higher degree of sialylation.
\end{abstract}

It is now widely accepted that the first step in insulin action is binding to specific receptors in target cell surface membranes (Kahn, 1976; Roth, 1979). Insulin receptors have been identified on cells of all vertebrates examined thus far. Although the interaction of insulin with its receptor has been well characterized in both intact cells and membrane preparations, very little is known concerning the exact molecular mechanism of the interaction because purification and direct chemical characteristization of the receptor have been difficult. Recently, we and others have obtained data on the structure of the insulin receptor using a variety of techniques. In this review, we briefly report our own data on the structural features of the insulin receptor. Information on this structure should enable us to better approach and define the molecular basis of insulin action.

(1) To whom all correspondance should be addressed. 


\section{Covalent binding of ${ }^{125}$ I-insulin.}

To bind ${ }^{125}$-insulin covalently to its receptor we used the technique originally described by Pilch and Czech (1979) and adapted by us to human cultured lymphocytes of the IM-9 line (Kasuga et al., 1981b). Briefly, ${ }^{125}$-insulin (5 nM) is bound to lymphocyte cell membranes. The membranes are spun down and the free hormone is discarded. The covalent crosslinking of the bound ${ }^{125}$-insulin is performed by adding the crosslinking agent, disuccinimidyl suberate, at a final concentration of $3 \times 10^{-5} \mathrm{M}$. The reaction is stopped by the addition of Tris, the membrane pellet is then solubilized in sodium dodecyl sulfate (SDS) and subjected to SDS-polyacrylamide gel electrophoresis (SDS-PAGE) under reducing conditions. Finally, the gel is autoradiographed.

When ${ }^{125}$-insulin was covalently crosslinked to human lymphocyte membranes by disuccinimidyl suberate, SDS-PAGE under reducing conditions revealed a major ${ }^{125}$-labeled band of mol wt 130,000 and minor bands of 300,000 and 95,000 (fig. 1A). To assess the specificity of these bands, 125 -insulin was

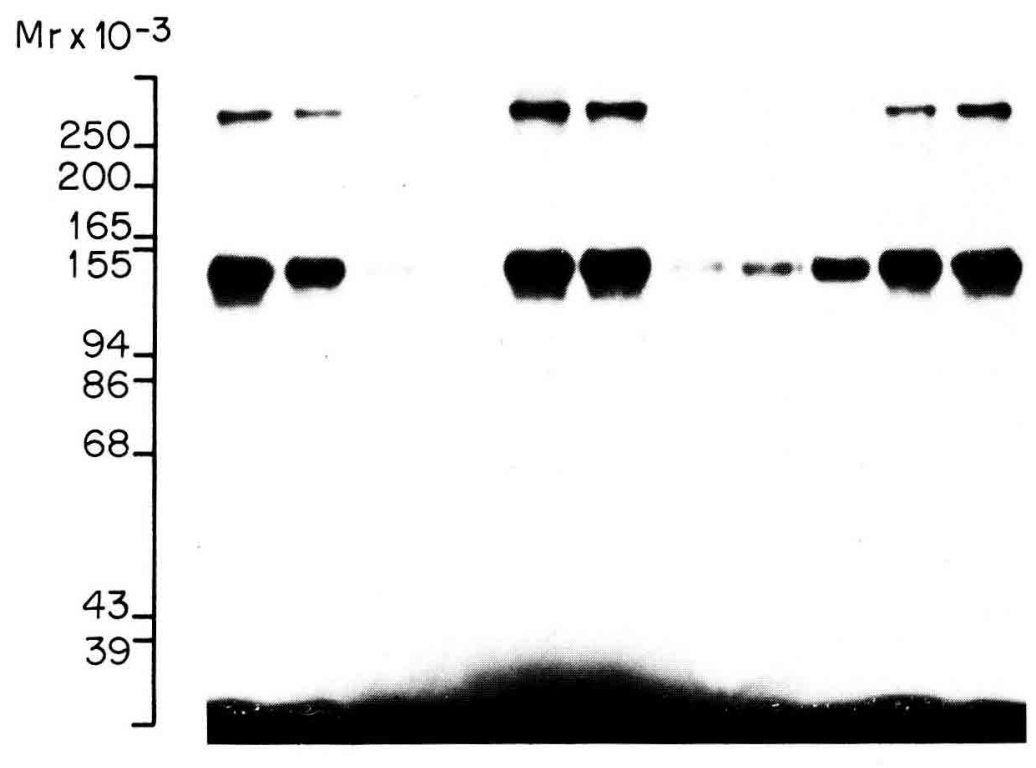

$\begin{array}{llllllllllllllllllll}A & B & C & D & E & F & G & H & \text { I } & J & K\end{array}$

FIG. 1. - Specificity of 125/-insulin-receptor complex crosslinked to human /ymphocyte membrane. The crude lymphocyte membranes $(0,4 \mathrm{mg})$ were incubated for 90 min at $15^{\circ} \mathrm{C}$ with $5 \mathrm{nM}{ }^{125}$ insulin in the absence (A) and the presence of insulin $(B: 5 \mathrm{nM}, \mathrm{C}: 50 \mathrm{nM}, \mathrm{D}: 5 \mu \mathrm{M})$, human growth hormone (E : $5 \mu \mathrm{M}$ ), ovine lactogen (F : $5 \mu \mathrm{M}), 0.2 \mathrm{mg} / \mathrm{ml}$ antireceptor $\operatorname{lgG}(\mathrm{G}$ : patient $\mathrm{B}-2, \mathrm{H}$ : patient $\mathrm{B}-5, \mathrm{I}$ : patient $\mathrm{B}-8$, J : patient $\mathrm{B}-6)$ or $0.2 \mathrm{mg} / \mathrm{ml}$ normal control $\mathrm{lgG}(\mathrm{K})$, crosslinked by disuccinimidyl suberate and electrophoresed under reducing conditions (100 mM DTT) followed by staining, drying and autoradiography.

A : control ; $B$ : insulin $\left(5 \times 10^{-9} \mathrm{M}\right): \mathrm{C}$ : insulin $\left(5 \times 10^{-8} \mathrm{M}\right) ; \mathrm{D}$ : insulin $\left(5 \times 10^{-6}\right.$ $\mathrm{M}) ; \mathrm{E}: \mathrm{hGH}\left(5 \times 10^{-6} \mathrm{M}\right) ; \mathrm{F}$ : ovine placental lactogen $\left(5 \times 10^{-6} \mathrm{M}\right) ; \mathrm{G}: \mathrm{B}-2, \mathrm{H}: \mathrm{B}-5, \mathrm{I}:$ B-8 and J: B-6: autoantibody against insulin receptor $(0,2 \mathrm{mg} / \mathrm{ml}) ; \mathrm{K}$ : normal $\operatorname{lgG}(0.2$ $\mathrm{mg} / \mathrm{mll}$. 
crosslinked to lymphocyte membranes in the presence of the following unlabeled hormones: insulin (figs. 1B, 1C, and 1D), human growth hormone (fig. 1E) and ovine placental lactogen (fig. 1F). The latter two hormones were chosen since it is known that the IM-9 lymphocyte has receptors for them. Insulin abolished both the $\mathrm{Mr}=130,000$ and 95,000 bands in a dose-dependent manner, but neither human growth hormone nor ovine placental lactogen had any effect on their labeling.

When ${ }^{125}$-insulin was crosslinked in the presence of anti-receptor IgG from the sera of four patients (B-2, B-5, B-8, B-6) with the syndrome of severe insulin resistance and acanthosis nigricans, the two bands disappeared in accordance with the titers of antibodies (Kahn et al., 1976 ; Van Obberghen and Kahn, 1981) (figs. 1G, 1H, 1I and 1J). In contrast, Ig from normal control sera had no effect on the labeling of the two bands (fig. 1K). Labeling of the $\mathrm{Mr}=300,000$ band, which barely entered the resolving gels, was specifically inhibited by insulin and anti-receptor antibody. This band might have been a high mol wt aggregate containing the $\mathrm{Mr}=130,000$ band or represented an incompletely reduced oligomeric receptor. Note that using the same affinity crosslinking technique, we have studied the structure of the receptor for insulin-like growth factors for IGF and identified two subtypes of IGF-receptors (Kasuga et al., 1981c, 1982).

We next examined the immunoprecipitability of insulin-binding subunits by antireceptor antibodies. After incubation with ${ }^{125} \mathrm{I}$-insulin and crosslinking, lymphocyte membranes were solubilized in $1 \%$ Triton X-100 and immunoprecipitated using anti-receptor IgG from a patient (B-2) with autoantibodies to the insulin receptor. Resolution of the immunoprecipitate in SDS-PAGE again revealed a major band of mol wt 130,000 and a minor band of 95,000 revealed only by prolonged exposure. No radioactivity was precipitated by normal lgG. Most importantly, preincubation of Triton-solubilized ${ }^{125}$-insulin receptor complexes with a high concentration of insulin $\left(5 \times 10^{-6} \mathrm{M}\right)$ inhibited subsequent immunoprecipitation of the two bands, whereas preincubation with the same concentration of human growth hormone was without effect (Kasuga et al., 1981b).

In summary, covalent crosslinking of 125 -insulin to cell membranes in SDSpolyacrylamide gel electrophoresis under reducing conditions revealed two species specific for the insulin receptor : a major band with a molecular weight of $130 \mathrm{~K}$ and a minor band with a molecular weight of approximately $95 \mathrm{~K}$. Antireceptor $\lg$ inhibited the formation of $\mathrm{Mr}=130,000$ and 95,000 insulin-receptor complexes identified by covalent crosslinking of 125 -insulin and could precipitated the preformed covalent ${ }^{125}$ I-insulin-receptor complex.

\section{Labeling of the protein moiety of the insulin receptor}

2.1. Biosynthetic labeling of the insulin receptor. - To label the receptor biosynthetically, IM-9 lymphocytes are cultured in the presence of ${ }^{35} \mathrm{~S}$ methionine for 14 hrs at $37{ }^{\circ} \mathrm{C}$; the cells are washed and the cell pellet is solubilized in Triton X-100 (Van Obberghen et al., 1981a, 1981b ; Kasuga et al., 1981a). The cell extract is then applied to a wheat germ agglutinin agarose column and 
desorption is performed with $\mathrm{N}$-acetyglucosamine. This lectin allows 20 -fold purification ot the insulin receptor with nearly $100 \%$ recovery of the receptor as determined by ${ }^{125}$-insulin binding. The labeled glycoproteins eluted from the column are then precipitated by anti-receptor antibodies. Finally, the immunoprecipitate is subjected to SDS-PAGE under reducing conditions and the labeled protein bands are identified by autoradiography.

Immunoprecipitation of ${ }^{35} \mathrm{~S}$-labeled cell proteins : ${ }^{35} \mathrm{~S}$-methionine was taken up and incorporated into proteins of IM-9 lymphocytes over a 14-hr period at $37^{\circ} \mathrm{C}$. More than $90 \%$ of the cell-associated radioactivity was incorporated into proteins as measured by precipitability in $5 \%$ trichloracetic acid. Of the $50 \mu \mathrm{Ci} / \mathrm{ml}$ added, $27 \%$ was present in cellular proteins at the end of the labeling period, corresponding to approximately $40 \times 10^{6} \mathrm{cpm}$ per $10^{6}$ cells. On the basis of theoretical calculation, $0.01-0.05 \%$ of this would be in the insulin receptor, if one assumes uniform label distribution. When the solubilized labeled glycoproteins were immunoprecipitated with serum from a normal individual, a few minor bands were observed ranging in molecular mass from 25 to 150 kilodaltons (kDal) (fig. 2, lane A). Immunoprecipitation with serum (B-2) containing autoantibodies against the insulin receptor revealed four additional bands on the autoradiographs : two major bands of apparent molecular mass 130 and $90 \mathrm{kDal}$ and two minor bands of molecular mass 200 and $70 \mathrm{kDal}$ (fig. 2, lane B).

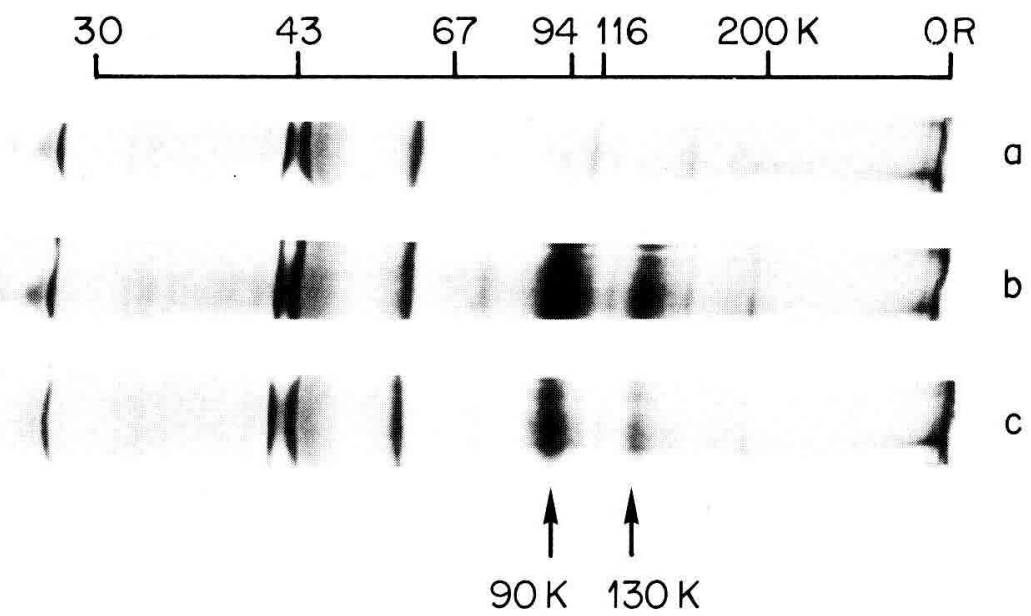

FIG. 2. - Immunoprecipitation of ${ }^{35} \mathrm{~S}$-labeled subunits of the insulin receptor. Cells were labeled with ${ }^{35}$ S-methionine and solubilized with Triton X-100; the insulin receptors were purified on wheat germ agglutinin-agarose and immunoprecipitation was performed. After solubilization, the immunoprecipitates were electrophoresed in a 5-15\% linear acrylamide gradient under reducing conditions. The gels were dried and subjected to autoradiography. The figure shows an autoradiograph of the gel. The different lanes correspond to the following immunoprecipitation conditions : $\mathrm{a}=$ normal serum $(1 / 800$ dilution or $25 \mu \mathrm{g} / \mathrm{ml} \mathrm{lgG}) ; \mathrm{b}=$ antireceptor serum B-2 $(1 / 800$ dilution or $25 \mu \mathrm{g} / \mathrm{ml}(\mathrm{gG}) ; \mathrm{c}=$ preincubation with insulin $(1.7 \mu \mathrm{M})$ followed by immunoprecipitation with antireceptor serum B-2 (1/800 dilution). 
Further evidence suggests that both the 130 and $90-\mathrm{kDal}$ bands, and possibly the 200-kDal band, were the components of the insulin receptor. We have previously shown that insulin bound to receptor reduces anti-receptor binding to and immunoprecipitation of the insulin receptor (Kahn et al., 1976; Van Obberghen and Kahn, 1981). Preincubation of solubilized ${ }^{35} \mathrm{~S}$-methionine-labeled glycoproteins with an excess of unlabeled insulin $\left(1.7 \times 10^{-6} \mathrm{M}\right)$ for 6 hrs prior to incubation with anti-receptor serum markedly decreased the appearance of both the 130 and the $90-\mathrm{kdal}$ bands (fig. 2, lanes B and C). Quantitative scanning of the autoradiographs revealed that preincubation with insulin caused decreases of 58 and $35 \%$ in the area of the 130 and 90-kDal bands, respectively, and a $25 \%$ decrease in the $200-\mathrm{kDal}$ band. Insulin was without significant effect on the other bands. Conversely, a higher concentration of anti-receptor antibodies $(50 \mu \mathrm{g} / \mathrm{ml})$ produced a moderate increase in the precipitation of the 130 and 90 kDal bands. Note that the ${ }^{35} \mathrm{~S}$ specifically immunoprecipitated by the antireceptor serum represented $0.01-0.02 \%$ of the cell-associated ${ }^{35} \mathrm{~S}$ radioactivity, which is of the same order of magnitude as predicted by theoretical consideration. Further, using the same biosynthetic labeling technique, we found an identical subunit structure of the insulin receptor in primary cultures of rat hepatocytes (Van Obberghen and Le Cam, 1981).

2.2. Cell surface labeling. - To label cell surface proteins, IM-9 lymphocytes were exposed to $\mathrm{Na}^{125}$ and lactoperoxidase (Harrison et al., 1982). The cells were solubilized in Triton X-100. After purification of labeled glycoproteins by elution from immobilized wheat germ lectin with $\mathrm{N}$-acetylglucosamine, insulin receptors were quantitatively immunoprecipitated using autoantibodies against the insulin receptors. Analysis of the immunoprecipitates by SDS-PAGE under reducing conditions followed by autoradiography revealed the specific precipitation of two major bands with molecular weights of 130,000 and 90,000 similar to the subunit composition found with biosynthetic labeling with ${ }^{35} \mathrm{~S}$-methionine. Note that a minor specific band of approximately 70,000 molecular weight could also be seen.

\section{Labeling of the carbohydrate moiety of the insulin receptor.}

3.1. Biosynthetic labeling of the insulin receptor. - The technique used to biosynthetically label the carbohydrate moiety of the insulin receptor is identical to the one applied to label the proteins, except that tritiated monosaccharides replace the ${ }^{35}$ S-methionine (Hedo et al., 1981b).

Cells grown for $14 \mathrm{hrs}$ in media containing $\mathrm{D}-\left({ }^{3} \mathrm{H}\right)$ glucosamine, L- $\left({ }^{3} \mathrm{H}\right)$ fucose, $\mathrm{D}-\left({ }^{3} \mathrm{H}\right)$ galactose or $\mathrm{D}-\left({ }^{3} \mathrm{H}\right)$ mannose incorporated $7-9,2,6$ or $1 \%$ of the total radioactivity, respectively, into trichloracetic acid-precipitable material. The cells were solubilized and the extracts subjected to lectin chromatography and immunoprecipitation. Analysis of the insulin receptor biosynthetically labeled by SDS-PAGE of the antireceptor serum precipitate showed the presence of two major labeled subunits of apparent molecular weight $134,000 \pm 2,000$ (SD, $\mathrm{n}=3$ ) and $98,000 \pm 1,500(\mathrm{SD}, \mathrm{n}=3$ ) and a minor component of molecular 


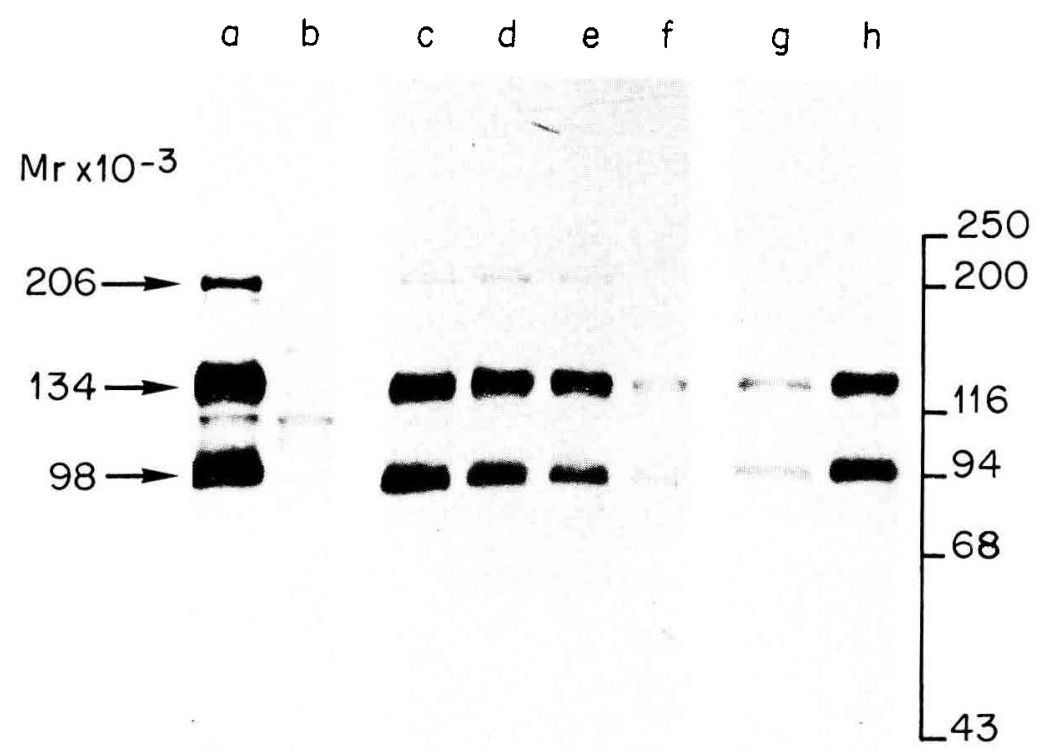

FIG. 3. - SDS-PAGE and autoradiography of $\left({ }^{3} \mathrm{H} /\right.$ glucosamine-labeled insulin receptors. IM-9 lymphocytes were cultured in the presence of $\left({ }^{3} \mathrm{H}\right)$ glucosamine and solubilized in Triton $X-100$; after purification on wheat germ agglutinin-agarose, the insulin receptors were immunoprecipitated with serum containing antireceptor antibodies. The immunoprecipitates were solubilized with SDS/DTT/2-mercaptoethanol and subjected to electrophoresis in SDS/PAGE. (Left) Immunoprecipitation with antireceptor serum from patient B-2 (lane a) and with nonimmune control serum (lane b). Both sera were diluted 1:400. (middle) Effect of insulin on immunoprecipitation by antireceptor antibodies. Antireceptor serum B-2 was used at dilutions of 1:400 (lanes $c$ and d) or 1:800 (lanes $e$ and $f$ ). Prior to immunoprecipitation, some labeled samples were incubated with $1.7 \mu \mathrm{M}$ insulin for $12 \mathrm{hrs}$ at $4{ }^{\circ} \mathrm{C}$ (lanes $\mathrm{d}$ and $\mathrm{f}$ ). Samples not incubated with insulin are shown for comparison (lanes $\mathrm{c}$ and e). (Right) Effect of down-regulation of insulin receptors on labeling of receptor subunits. IM-9 lymphocytes were incubated with $\left({ }^{3} \mathrm{H}\right)$ glucosamine in the absence (lane h) and the presence (lane g) of $0.1 \mu \mathrm{M}$ insulin for $12 \mathrm{hrs}$ at $37^{\circ} \mathrm{C}$, resulting in a 70 $\%$ decrease in receptor concentration as measured by ${ }^{125}$-labeled insulin binding. Subsequently, the cells were washed extensively to remove bound insulin and processed as described above. Immunoprecipitation was performed with antireceptor serum B-2.

weight 206,000 $\pm 2,500(S D, n=3$ ) (fig. 3, lane a). The control serum precipitated only two minor bands of $\mathrm{Mr} 116,000$ and 40,000 (lane b) which were also observed with the antireceptor serum. The ratio of activity in the Mr 134,000 band versus that in the $\mathrm{Mr} 98,000$ band was $1.8: 1$ for $\left({ }^{3} \mathrm{H}\right)$ glucosamine, 1.9:1 for $\left({ }^{3} \mathrm{H}\right)$ fucose and $2: 1$ for $\left({ }^{3} \mathrm{H}\right)$ mannose. A somewhat lower ratio was observed with galactose (1.2:1). In contrast to carbohydrate labeling in which the $\mathrm{Mr} 134,000$ subunit was always more prominent, protein labeling with $\left({ }^{35} \mathrm{~S}\right)$ methionine preferentially labeled the $\mathrm{Mr} 98,000$ band $(\mathrm{Mr} 134,000 / \mathrm{Mr} 98,000=0.3: 1)$. 
To further evaluate the specificity of the immunoprecipitation of the labeled bands, we preincubated the samples with $1.7 \times 10^{-6} \mathrm{M}$ insulin before immunoprecipitation. Insulin effectively inhibited immunoprecipitation of all three subunits (fig. 3, middle). As judged by assaying the eluted radioactivity, insulin quantitatively reduced the intensity of the three bands by $30 \%$ when a $1: 400$ dilution of the antiserum was used for precipitation (lanes $\mathrm{c}$ and d) and by $65 \%$ when a 1:800 dilution was used (lanes $e$ and f). Two other findings further indicate that the labeled glycoproteins were subunits of the insulin receptor. First, sera from five different patients with antibodies to the insulin receptor precipitated the same labeled bands, and the extent of precipitation correlated well with their titer of antireceptor antibodies. Second, the decrease in the number of insulin receptors observed in down-regulation of the insulin receptor was accompanied by a decrease in the labeling of these bands (lanes $g$ and $h$ ).

3.2 External labeling of insulin receptors. - To study the external carbohydrate moiety of the insulin receptors, the cell surface of intact lymphocytes was labeled with $\mathrm{NaB}^{3} \mathrm{H}_{4}$ using either the galactose oxidase (acts on nonreducing terminal galactose and $\mathrm{N}$-acetylgalactosamine) technique or the periodate (oxidizes sialic acid) technique (Hedo et al., 1981b). Briefly, the first step is to expose intact IM-9 lymphocytes to either galactose oxidase or periodate, resulting in the formation of sugar aldehydes in galactosyl and Nacetylgalactosaminyl residues with the first method and in sialic acid residues with the second method. The second step is to reduce the sugar aldehydes with tritiated sodium borohydride. Thereafter, the cells are solubilized in Triton X-100 and immunoprecipitated with antireceptor serum and control serum. Finally, the immunoprecipitates are subjected to SDS-PAGE followed by autoradiography. Using the galactose oxidase method, incubation with galactose oxidase alone followed by borohydride reduction labeled only the 134,000 molecular weight subunit of the insulin receptor. Since sialic acid residues are often linked to penultimate galactosyl groups, increased labeling efficiency has been achieved for different cell surface glycoproteins by treating the cells with neuraminidase to remove sialic acids prior to labeling with galactose oxidase. Similar observations were found with the insulin receptor. Indeed, treatment with neuraminidase and galactose oxidase enhanced the labeling of the 134,000 molecular weight subunit and also revealed the 98,000 molecular weight subunit as well as the 206,000 molecular weight component.

To reveal terminal sialic acid residues, IM-9 lymphocytes were labeled by using the periodate $/ \mathrm{NaB}^{3} \mathrm{H}_{4}$ method, and the cells were then processed as after the galactose oxidase procedure. After periodate treatment, $\cdot \mathrm{NaB}^{3} \mathrm{H}_{4}$ preferentially labeled the $\mathrm{Mr} 98,000$ subunit, although a faint $\mathrm{Mr} 134,000$ band was also observed. When the cells were treated with neuraminidase prior to labeling, the intensity of the $\mathrm{Mr} 98,000$ band decreased by $35 \%$ (as estimated from the radioactivity), while that of the Mr 134,000 component disappeared. Thus, as reported for other glycoproteins, sialic acid residues that are radiolabeled by this method may not all be accessible to neuraminidase. 


\section{Discussion and conclusions.}

Using both biosynthetic and external labeling techniques, we have demonstrated that the insulin receptor consists of two major subunits with a molecular weight of approximately 135,000 and 95,000 , respectively. These two major subunits are glycoproteins. Note that with biosynthetic labeling using either ${ }^{35}$ S-methionine (Van Obberghen et al., 1981a ; Kasuga et al., 1981a) or tritiated monosaccharides (Hedo et al., 1981b), we routinely found a minor component with a molecular weight of 210,000 . At the present time, it is not clear whether this component represents a biosynthetic precursor of the receptor or whether it is a receptor-associated glycoprotein involved in the regulation of the receptor. Our data and observations from other laboratories have led to the suggestion that the insulin receptor is a heterodimer of the 135,000 and 95,000 subunits and, in fact, has an immunoglobulin-like structure with heavy and light chains held together by disulfide bonds (Kasuga et al., 1981b ; Jacobs et al., 1980 ; Massague and Czech, 1980). Both subunits of the insulin receptor contain carbohydrate, whereas only the heavy chains of the immunoglobulin molecule are glycosylated. The incorporation of all four labeled monosaccharides (fucose, mannose, galactose and glucosamine) into the two major subunits of the insulin receptor suggests that both are likely to contain carbohydrate chains of the complex, N-linked type (Kornfeld and Kornfeld, 1980). This suggestion is in good agreement with findings on differential lectin binding (Hedo et al., 1981a) and with the observation that tunicamycin, an antibiotic that blocks glycosylation of $\mathrm{N}$-linked glycoproteins, induces a depletion of insulin binding activity in 3T3-L1 (Rosen et al., 1979) and IM-9 (Keefer and De Meyts, 1981) cells. However, the possible presence of 0 -linked carbohydrate chains in the receptor subunits cannot be excluded. The external labeling techniques demonstrate that the protein and carbohydrate moiety of both subunits is exposed at the external cell surface. Further, labeling of the external oriented carbohydrates revealed remarkable differences in the nonreducing termini of the carbohydrate chains of both major subunits. Indeed, the galactose oxidase $/ \mathrm{NaB}^{3} \mathrm{H}_{4}$ method preferentially labeled the 134,000 molecular weight subunit, whereas the periodate $/ \mathrm{NaB}^{3} \mathrm{H}_{4}$ preferentially labeled the 95,000 molecular weight subunit.

In conclusion, the various labeling techniques have enabled us to gather structural information about the insulin receptor and its subunits. The fact of being able to label both the carbohydrate and protein moiety of the insulin receptor adds a new dimension to the study of receptor structure, function and turnover, not only under physiological conditions but, more importantly, in disease states with altered insulin action. Finally, this information should provide us with a better insight for defining the molecular basis of insulin action.

$8^{e}$ Réunion du groupe, Développement I.N.R.A., Tours, 12-13 mai 1982.

Acknowledgements. - We wish to thank A. Rainaud (Nice, France) for her excellent secretarial assistance in the preparation of this manuscript. 
These studies reflect the contribution and cooperation of many colleagues and collaborators, including Harrison, L. C., Kahn, C. R., Yamada, K. and Roth, J. We gratefully thank them.

Résumé. Structure du récepteur de l'insuline: études par des techniques de marquage externe et interne.

Nous avons caractérisé la structure du récepteur insulinique par des techniques de marquage biosynthétique (" marquage interne ") et de marquage des glycoprotéines situées à la surface externe des cellules (" marquage externe »). En résumé : 1) Le récepteur est un oligomère de 300000 daltons (dal), composé de 2 sous-unités dont le poids moléculaire est d'environ 134000 dal et 95000 dal. Ces 2 sous-unités sont liées entre elles par des ponts disulfures. 2) Ces sous-unités sont des glycoprotéines du type " complexe » ayant toutes les 2 une partie de leur composante glucidique et de leur composante protéique exposée à la surface externe des cellules. 3) II existe des différences importantes au niveau des groupes terminaux non-réducteurs des chaînes glucidiques. Dans la sous-unité de poids moléculaire 134000 dal, on trouve plus de résidus galactosyl et/ou $\mathrm{N}$ acétylgalactosaminyl ; alors que la sous-unité de poids moléculaire 95000 dal contient un plus grand nombre d'acides sialiques.

\section{References}

HARRISON L..C., ITIN A., KASUGA M., VAN OBBERGHEN E., 1982. The insulin receptor of the human lymphocyte : insulin-induced down-regulation of 126,000 and 90,000 glycosylated subunits. Diabetologia, 22, 233-238.

HEDO J. A., HARRISON L. C., ROTH J., 1981a. Binding of insulin receptors to lectins : evidence for common carbohydrate determinants on several membrane receptors. Biochemistry, 20, 3385-3393.

HEDO J. A., KASUGA M., VAN OBBERGHEN E., ROTH J., KAHN C. R., 1981b. Direct demonstration of glycosylation of insulin receptor subunits by biosynthetic and external labeling: evidence for heterogeneity. Proc. nat. Acad. Sci, USA, 78, 4791-4795.

JACOBS S., HAZUMN E., CUATRECASAS P., 1980. The subunit structure of rat liver insulin receptor. Antibodies directed against the insulin-binding subunit. J. biol. Chem., 255, 69376940.

KAHN C. R., 1976. Membrane receptors for hormones and neurotransmitters. J. Cell Biol., 70, 261-286.

KAHN C. R., FLIER J. S., BAR R. S., ARCHER J. A., GORDEN P., MARTIN M. M., ROTH J., 1976. The syndromes of insulin resistance and acanthosis nigricans. Insulin-receptor disorders in man. N.-Engl. J. Med., 294, 739-745.

KASUGA M., KAHN C. R., HEDO J. A., VAN OBBERGHEN E., YAMADA K. M., 1981a. Insulininduced receptor loss in cultured human lymphocytes is due to accelerated receptor degradation. Proc. nat. Acad. Sci. USA, 78, 6917-6921.

KASUGA M., VAN OBBERGHEN E., HARRISON L. C., YAMADA K., 1981b. Autoantibodies against the insulin receptor recognize the insulin binding subunits of an oligomeric receptor. Diabetes, 30, 354-357.

KASUGA M., VAN OBBERGHEN E., NISSLEY S. P., RECHLER M. M., 1981c.Demonstration of two subtypes of insulin-like growth factor receptors by affinity cross-linking. J. biol. Chem., 256, 5305-5308.

KASUGA M., VAN OBBERGHEN E., NISSLEY S. P., RECHLER M. P., 1982. Structure of the insulin-like growth factor receptor in chick embryo fibroblasts. Proc. nat. Acad. Sci. USA, 79, $1864-1868$. 
KEEFER L. M., DE MEYTS P., 1981. Glycosylation of cell surface receptors: tunicamycin treatment decreases insulin and growth hormone binding to different levels in cultured Iymphocytes. Biochem. Biophys. Res. Commun., 101, 22-29.

KORNFELD R., KORNFELD D., 1980. Structure of glycoproteins and their oligosaccharide units, 1-34. In LENNARZ W. J., The Biochemistry of glycoproteins and proteog/ycans. Plenum, New York.

MASSAGUE J., CZECH M. P., 1980. Multiple redox forms of the insulin receptor in native liver membranes. Diabetes, 29, 945-947.

PILCH P. F., CZECH M. P., 1979. Interaction of cross-linking agents with the insulin effector system of isolated fat cells. J. biol. Chem., 254, 3375-3381.

ROSEN O. M., CHIA G. H., FUNG C., RUBIN C. S., 1979. Tunicamycin-mediated depletion of insulin receptors in 3T3-L1 adipocytes. J. Cell Physiol., 99, 37-42.

ROTH J., 1979. Receptors for Peptide Hormones. In DE GROOT L., Endocrinology, Vol. 3, 2037-2054. Grune \& Stratton, New York.

VAN OBBERGHEN E., KASUGA M., LE CAM A., HEDO J. A., ITIN A., HARRISON L. C., 1981a. Biosynthetic labeling of the insulin receptor: studies of subunits in cultured human IM-9 lymphocytes. Proc. nat. Acad. Sci. USA, 78, 1052-1056.

VAN OBBERGHEN E., KAHN C. R., 1981. Autoantibodies to the insulin receptor. Mol. cell Endocr., 22, 277-293.

VAN OBBERGHEN E., KASUGA M., HARRISON L. C., LE CAM A., HEDO J. A., 1981b. The subunit structure of the insulin receptor identified by external and internal labeling techniques, 29-36. In D. ANDREANI, R. DE PIRRO, R. LAURO, J. OLEFSKY, J. ROTH, Current views on insulin receptors, Serono Symposia, Vol. 41, Acad. Press, London and New York.

VAN OBBERGHEN E., LE CAM A., 1981. Identification and turnover of the insulin receptor in primary cultures of adult rat hepatocytes. Diabetologia, 21, 339.

(The list of references is very incomplete. A better list may be found in the original papers.) 